\section{Case Reports in Neurology}

Case Rep Neurol 2021;13:108-118

DOI: $10.1159 / 000512265$

Published online: February 16, 2021

2021 The Author(s)

Published by S. Karger AG, Basel

www.karger.com/crn

This article is licensed under the Creative Commons Attribution-NonCommercial 4.0 International License (CC BY-NC) (http://www.karger.com/Services/OpenAccessLicense) Usage and distribution for commercial purposes requires written permission.

\title{
A Patient with Noonan Syndrome with a KRAS Mutation Who Presented Severe Nerve Root Hypertrophy
}

\author{
Yoshihito Ando a, b, c Mikio Sawadab, c Tadataka Kawakami ${ }^{\text {b, d }}$ \\ Mitsuya Moritab, e Yoko Aoki ${ }^{f}$
}

aDepartment of Internal Medicine, Josai Hospital, Yuki, Japan; bDivision of Neurology, Department of Internal Medicine, Jichi Medical University Hospital, Shimotsuke, Japan; 'Department of Neurology, Haga Red Cross Hospital, Moka, Japan; dDepartment of Neurology, Shin Oyama City Hospital, Oyama, Japan; eDivision of Rehabilitation, Jichi Medical University Hospital, Shimotsuke, Japan; fDepartment of Medical Genetics, Tohoku University School of Medicine, Sendai, Japan

\section{Keywords}

Noonan syndrome - Nerve root hypertrophy $\cdot$ KRAS gene mutation - Ras/MAPK pathway · RASopathy
Abstract

$\begin{array}{ll} & \text { Yoshihito Ando } \\ \text { Department of Internal Medicine, Josai Hospital } & \\ & 10748-24 \text { Yuki } \\ \text { Yuki, Ibaraki 307-0001 (Japan) } \\ \text { yacht-po@jichi.ac.jp }\end{array}$

We report a 45-year-old female with clinical features resembling Noonan syndrome (NS) who presented with significant nerve root hypertrophy. She was initially diagnosed with CharcotMarie-Tooth disease because her gait disturbance gradually deteriorated and nerve conduction velocity was reduced. However, she did not carry a PMP22 gene mutation. RASopathies are a group of phenotypically overlapping developmental syndromes caused by germline mutations that encode components of the Ras/MAPK signaling pathway. These disorders include NS, cardiofaciocutaneous (CFC) syndrome, and Costello syndrome and are associated with molecular abnormalities in the Ras/MAPK pathway. The patient was suspected to have NS and related disorders because of pulmonary artery stenosis, lymphedema, distinctive facial 


\section{Case Reports in Neurology}

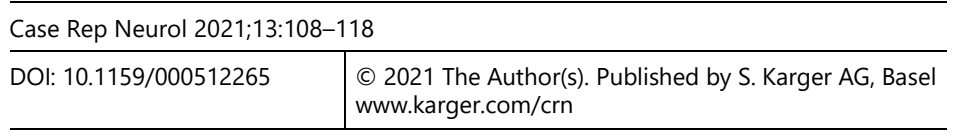

Ando et al.: Noonan Syndrome with KRAS Mutation and Nerve Root Hypertrophy

appearance, and intellectual disability. Genetic analysis identified a heterozygous de novo mutation in KRAS (c.211T>G, p.Tyr71Asp), which is usually observed in patients with NS or CFC syndrome. Although our patient was diagnosed with NS, she revealed clinical manifestations that were typical to CFC syndrome, including intellectual disability. It has been reported that some patients diagnosed with RASopathies with mutations in PTPN11, SOS1, or KRAS developed nerve root hypertrophy. These results suggest that nerve root hypertrophy may be associated with RASopathy, although the onset mechanisms of nerve root hypertrophy are unknown.

\section{Introduction}

Noonan syndrome (NS) is a congenital malformation syndrome characterized by short stature, intellectual disability, distinctive facial appearance, congenital heart defects, hypertrophic cardiomyopathy, pectus deformity, and lymphatic malformation. In the majority of patients NS is a congenital malformation syndrome, characterized by short stature, clinically diagnosed, but molecular genetic testing is performed in $70 \%$ of cases. Nine gene mutations (PTPN11, 50\%; SO1S, 10-13\%; RAF1, 5\%; RIT1, 5\%; KRAS, <5\%; NRAS, 8 individuals and 4 families; $B R A F,<2 \%$; $M A P 2 K 1,<2 \%$; and $L Z T R 1$, unknown) related to this disease have been reported $[1,2]$.

The Ras/mitogen-activated protein kinase (Ras/MAPK) pathway is a signal transduction pathway that controls cellular proliferation, differentiation, and death. "Ras/MAPK syndrome" or "RASopathy" has been proposed to describe characteristic congenital disorders that have been associated with gene mutations encoding members of the Ras/MAPK pathway. The RASopathies include NS, Costello syndrome, cardiofaciocutaneous (CFC) syndrome, NS with multiple lentigines (formerly called LEOPARD [lentigines, electrocardiographic abnormalities, ocular hypertelorism, pulmonary stenosis, abnormalities of the genitals, retarded growth, deafness syndrome]), NS-like syndrome, and neurofibromatosis type 1 (NF1). These syndromes frequently overlap and coexist with malignant tumors [3].

We report the case of a 45-year-old female who was suspected to have NS or related disorders accompanied by severe peripheral nerve hypertrophy. We identified a KRAS mutation in this case.

\section{Case Presentation}

The patient was a 45-year-old female, with no similar cases or consanguineous marriages in her family line. 


\section{Case Reports in Neurology}

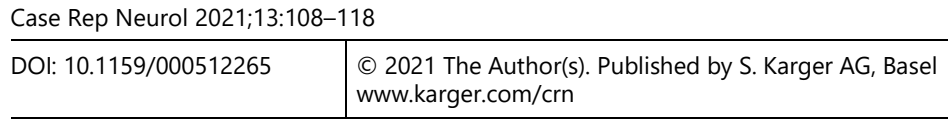

Ando et al.: Noonan Syndrome with KRAS Mutation and Nerve Root Hypertrophy

\section{Past History}

The patient underwent surgery for pulmonary artery stenosis at the age of 1 year and lymphatic duct bypass surgery for lymphedema of the left leg at the age of 15 years.

\section{Illness}

The patient could not walk until the age of 14 months and was slender since childhood. She could walk slowly, but not for long distances. Her lower limb strength, particularly in the distal part, gradually weakened, starting at the age of 34 years. She was unable to walk and maintain a standing position at the age of 37 years. She presented with intermittent severe pain in the left abdomen at the age of 44 years. A retroperitoneal tumor was revealed by abdominal computed tomography (CT). This tumor was believed to originate from the lumbar neural plexus, as indicated by abdominal magnetic resonance imaging (MRI). She could sit in a wheelchair for only a short time and was almost bedridden at admission.

\section{Intelligence Examination}

The patient's verbal, performance, and total intelligence quotient scores were 60,53 , and 59, respectively, as assessed by the Wechsler Adult Intelligence Scale - revised, which was equivalent to a mental age of 9 years 8 months according to the Tanaka-Binet Intelligence Scale.

\section{Physical Findings}

The patient had short stature, emaciation (body height $145 \mathrm{~cm}$ (1st centile), body weight $31 \mathrm{~kg}$ ( $1 \mathrm{st}$ centile), body mass index $14.7 \mathrm{~kg} / \mathrm{m}^{2}$ ), and a characteristic facial appearance (lowset hairline, hypertelorism, exophthalmos, flat root of the nose, wide wings of the nose, thick lower lips, high palate, wide interdentium, malocclusion, and macroglossia) (Fig. 1). The left eye showed exotropia, but she had no complaints of diplopia. Similarly, she presented with no hearing difficulties or face and neck muscle weakness. Slight anemia was observed in the palpebral conjunctiva, with no abnormality in the iris, including Lisch nodule. Tumor and swelling of the thyroid gland were not observed. A cardiac systolic murmur, Levine IV/VI grade, could be heard in the right sternum margin area. The abdominal wall was soft and flat, bowel sounds were normal, and no tumors were detected. The vulva showed red-brown pigmentation, eczema, and marginal swelling. Flexion contractures were observed in the metacarpophalangeal and interphalangeal joints of both hands. Significant bilateral leg swelling, talipes equinus contracture, and hallux valgus were observed. Hypertrophic peripheral nerve bundles were detected in the supraclavicular and popliteal fossa.

\section{Neurological Findings}

There was muscular weakness, with severer amyotrophy and hypotonicity in the distal limbs than in the proximal regions. The results of manual muscle testing were as follows: upper limb, good; hand, poor; proximal lower limb, trace; and distal lower limb, zero. Deep tendon reflexes were not evident, and pathological reflexes were not observed. Vibration sense was deteriorated in the distal lower limbs, and the perception of temperature, touch, and position had disappeared in the distal lower limb, starting at the knee joint. 


\section{Case Reports in Neurology}

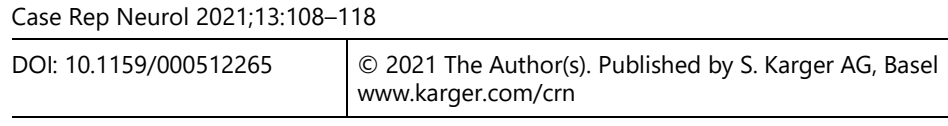

Ando et al.: Noonan Syndrome with KRAS Mutation and Nerve Root Hypertrophy

Blood and Cerebrospinal Fluid Test Findings

There were no abnormalities in major biochemical measures, thyroid hormone, or immunoglobulins, except for iron deficiency (red blood cells, $592 \times 10^{4} / \mu \mathrm{L}$; hemoglobin, $9.6 \mathrm{~g} / \mathrm{dL}$; hematocrit, 31.8\%; mean corpuscular volume, $53 \mathrm{fL}$; Fe, $9 \mu \mathrm{g} / \mathrm{dL}$; unsaturated iron-binding capacity, $375 \mu \mathrm{g} / \mathrm{dL}$; and ferritin, $<1.0 \mathrm{ng} / \mathrm{mL}$ ). A fecal occult blood test was negative. Proteinuria and urinary occult blood were observed. The cerebrospinal fluid test findings were as follows: cell count, $12 / \mu \mathrm{L}$ (only mononuclear cells); protein, $790 \mathrm{mg} / \mathrm{dL}$; glucose, $60 \mathrm{mg} / \mathrm{dL}$; $\mathrm{Cl}, 121 \mathrm{mEq} / \mathrm{L}$; myelin basic protein, $504 \mathrm{pg} / \mathrm{mL}(<102)$; and no oligoclonal band.

\section{Imaging Examinations}

Brain MRI showed slight brain atrophy and several high-intensity lesions in deep white matter on T2-weighted images. Vertebral MRI showed hypertrophy of the brachial plexus (Fig. 2a), intercostal nerve, and lumbar plexus (Fig. 2b). Abdominal MRI showed a poorly enhanced tumor lesion $(14 \times 48 \mathrm{~mm})$ around the abdominal aorta, celiac artery, superior mesenteric artery, and inferior vena cava (Fig. 2c). Lower limb, pelvis, and thigh MRI (Fig. 2d-f) showed severe thickening of the sciatic (diameter $25 \mathrm{~mm}$ ) and tibial nerves. However, clear thickening of the sural nerve was not confirmed on MRI image. Echocardiography showed bilateral ventricular outlet stenosis, with normal left ventricle function.

\section{Electrophysiological Examinations}

Electrocardiography showed sinus rhythm, incomplete right bundle branch block, and pulmonary artery hypertension pattern. Nerve conduction studies showed deteriorated compound muscle action potentials in both median nerves, and conduction velocities were $18.8 \mathrm{~m} / \mathrm{s}$ on the left side and $18 \mathrm{~m} / \mathrm{s}$ on the right side. Compound muscle action potentials of both ulnar nerves, common peroneal nerves, and posterior tibial nerves were absent. The sensory nerve action potential was deteriorated in the right median nerve, and conduction velocity was decreased by $26 \mathrm{~m} / \mathrm{s}$. Sensory nerve action potentials of both ulnar nerves, sural nerves, and left median nerve were absent. Conduction blocking was not clear, but temporal dispersion was observed in the right common peroneal nerve.

\section{Pathological Findings}

A sural nerve biopsy found very few large, myelinated fibers, some onion bulb lesions, and no inflammatory cells (Fig. 3).

\section{Genetic Analysis}

G-band karyotyping showed a normal female karyotype, $46 \mathrm{XX}$. No PMP22 gene domain duplication or deletion was identified by fluorescence in situ hybridization. Genomic DNA was isolated from the patient's leukocytes after receiving informed consent. All coding exons and flanking introns in PTPN11, exons 1, 2, and 5 in KRAS, exon 1 in HRAS, exons 6 and 11-16 in $B R A F$, exon 7 in $R A F 1$, and exons 2 and 3 in $M A P 2 K 1 / 2$ were amplified by polymerase chain reaction. After amplification, the polymerase chain reaction products were gel-purified and sequenced on the ABI 3130 automated DNA sequencer (Applied Biosystems, Carlsbad, CA,

\section{Karger'"}




\section{Case Reports in Neurology}

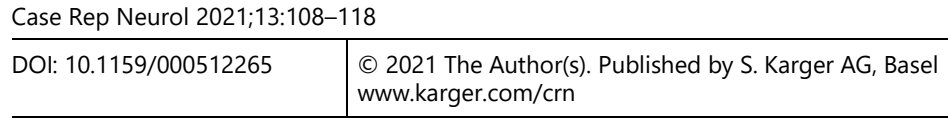

Ando et al.: Noonan Syndrome with KRAS Mutation and Nerve Root Hypertrophy

USA). A heterozygous missense variant (c.211T >G, p.Tyr71Asp) was identified in exon 2 of KRAS in the patient's DNA. The variant was not detected in the parental samples.

\section{Discussion and Conclusion}

The most particular points of this case were severe nerve root hypertrophy, from the cervical spinal nerves to the sacral plexus, and retroperitoneal plexus swelling, which caused intense pain. Since our case did not have café-au-lait spot, Lisch nodule, or neurofibroma, we determined that peripheral nerve hypertrophy was not caused by NF1 and did not perform gene analysis of NF1. However, a subtype of NF1 called spinal NF1 that lacks skin symptoms, which are the core of diagnostic criteria, has been reported [4]. The spinal magnetic resonance image and progressive symptoms of peripheral neuropathy such as walking disorders are very similar to the findings of our patients. Our patient has NS based on physical examination and genetic analysis. Judging by its clinical course, we considered the possibility of CharcotMarie-Tooth disease type 1A, but we could not detect PMP22 (17p11.2) duplication or mutation. Our patient has distinctive facial appearance, pulmonic stenosis, lymphedema, and intellectual disability, suggesting NS and related disorders. We examined hot spot mutations in PTPN11, RAF1, HRAS, KRAS, BRAF, and MAP2K1/2, the causative genes for Ras/MAPK syndrome. A heterozygous KRAS gene mutation (c.211T $>$ G, p.Tyr71Asp) has been identified in patients. KRAS mutations have been identified in patients with NS or CFC syndrome. Our patient was diagnosed with NS based on the physical findings and the presence of KRAS gene mutation (c.211T $>$ G, p.Tyr71Asp). Alternatively, the patient may be diagnosed with CFC syndrome because of intellectual disability.

Silburn et al. [5] reported 5 patients with NS, with nerve root hypertrophy, in one family. On the basis of our literature search, this report represents the earliest report of NS with nerve root hypertrophy. The diagnosis of NS was based on clinical features, and 4 of the 5 patients had PMP22 duplication based on a DNA dosage test, and nerve conduction studies revealed abnormalities. The authors described a proband in detail. The 37-year-old female patient with NS, with PMP22 duplication, presented progressive muscle weakness and sensory disturbance of the extremities. MRI showed thickening of cervical and lumbar nerve roots and revealed an 8- to $10-\mathrm{cm}$ tumor in the pelvic cavity. Biopsies of the sural nerve and the intrapelvic tumor showed myelinated fiber loss, demyelination, and onion bulb formation in both. The clinical course, the image views, and the pathological findings of this described patient greatly resemble those of our patient. Moreover, the proband's daughter was diagnosed with NS, without PMP22 duplication. She presented significant thickening of the lumbosacral nerve roots on MRI. Although she presented a café-au-lait spot, she did not fulfill the other criteria for NF1. Therefore, the authors concluded that the nerve root hypertrophy observed in this family was not caused by PMP22 but may, instead, represent a rare phenotype of NS [5]. We believe that our patient has a similar disease to that described for their patients, supporting their conclusion that peripheral nerve hypertrophy may be a phenotype of NS.

After the report by Silburn et al. [5], additional RASopathy cases associated with peripheral nerve hypertrophy were reported (Table 1). Some patients with CFC syndrome with 


\section{Case Reports in Neurology}

Case Rep Neurol 2021;13:108-118

DOI: $10.1159 / 000512265$

(C) 2021 The Author(s). Published by S. Karger AG, Basel www.karger.com/crn

peripheral nerve disorders have been reported. Manci et al. [6] reported an autopsy case of a 7-year-old boy with peripheral nerve hypertrophy and onion bulb formation. DeRoos et al. [7] reported the case of a 27-year-old man with marginal demyelination and axonopathy, diagnosed by nerve conduction studies. In these two reports, gene analysis was not performed. Stark et al. [8] reported 3 patients with CFC syndrome in two families. The child showed gait developmental abnormalities. He did not carry any PMP22 mutations but was found to carry the same KRAS point mutation (c.211T >C, p.Tyr71His) observed in our patient. Unfortunately, as the MRI images were not shown, whether nerve root hypertrophy existed is not clear. A sporadic patient in another family presented with a different $K R A S$ gene mutation (c.439A $>\mathrm{G}$, p.Lys147Glu). Stark et al. [8] concluded that peripheral nerve disorder is not an accidental complication but is, instead, a phenotype of CFC syndrome.

The p.Tyr71Asp, p.Tyr71His mutation in KRAS may be closely related to the peripheral nerve disorders observed in RASopathy, including NS and CFC syndrome. However, patients with LEOPARD syndrome [9], NS with multiple lentigines [10,11], and nerve root hypertrophy, associated with PTPN11 mutations, have also been reported. Bertola et al. [12] found a $K R A S$ mutation in a patient who also presented with nerve root hypertrophy. Santoro et al. [13] reported an SOS1 gene mutation in a case that was clinically diagnosed with NF1 and exhibited an intermediate NS phenotype. The MRI images of this case resemble those of our case, and the authors summarized comparisons between previous detailed reports of RASopathies with nerve root hypertrophy. The following mutations have been reported: SOS1 (p.Ser548Arg), KRAS (p.Lys147Glu, p.Lys5Glu), and PTPN11 (p.Thr468Met, p.Thr279Cys) [13].

Vizcaino et al. [14] reported an 11-year-old boy with thickening from the nerve root to the peripheral nerve. The patient did not present any specific RASopathy features other than the café-au-lait spot. The patient had a KRAS alteration in the peripheral nerve and cutaneous melanocyte specimens, although the mutation was not observed in the blood sample, supporting a mosaic presentation of RASopathy. Furthermore, the authors confirmed the accumulation of phospho-extracellular signal-regulated kinase in peripheral nerve specimens and concluded that the activation of the local Ras/MAPK system may cause Schwann cells to grow, resulting in neurothickening [14]. There are many overlapping phenotypes among the various RASopathies. Moreover, the phenotypes among individual cases with the same gene mutation can vary widely. The diagnosis of RASopathy by phenotype may be meaningless through the development of genetic analyses.

In recent reviews of NS, neurological problems included delayed mental development and co-occurrence of tumors; however, no description of a neurological form was included $[1,2]$. Since MRI and CT scans are regularly performed in patients with RASopathies, the occult phenotype of a neurological form, such as nerve root hypertrophy, will likely become more obvious.

At present, mutations associated with nerve root hypertrophy have been reported in three genes - PTPN11, SOS1, and KRAS - which are relatively frequent genes identified in NS and constitute a series of cascades in the Ras/MAPK pathway [3]. The reason why mutations in these different genes result in similar abnormalities is not currently understood. Moreover, why cases with point mutations in the same gene can differ between the presentations of 


\section{Case Reports in Neurology}

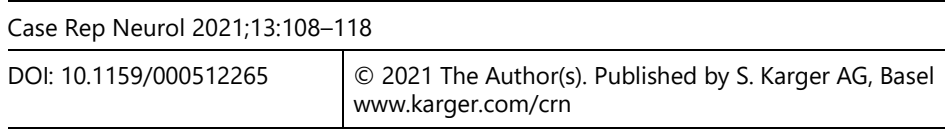

Ando et al.: Noonan Syndrome with KRAS Mutation and Nerve Root Hypertrophy

nerve root hypertrophy is also not clear. There may be a common mechanism underlying nerve root thickening because spinal NF1 is a type of RASopathy. Further investigation and case report data remain necessary to determine which point mutations are specifically associated with the underlying mechanisms that result in nerve root hypertrophy.

\section{Acknowledgment}

The authors thank Prof. Hirosihi Takashima (Department of Neurology and Geriatrics, Kagoshima University Graduate School of Medical and Dental Sciences), who researched gene analysis of Charcot-Marie-Tooth disease. They would like to thank Enago (www.enago.jp) for English language review.

\section{Statement of Ethics}

The patient died at the age of 47 years, and we received written informed consent for the publication of the case including the use of facial images from the patient's father and sister.

\section{Conflict of Interest Statement}

The authors have no conflicts of interest to declare.

\section{Funding Sources}

The authors did not receive any funding support.

\section{Author Contributions}

Inpatient medical examination: Y. Ando, M. Sawada, M. Morita. Outpatient medical examination: T. Kawakami. Manuscript - writing of the first draft: Y. Ando. Manuscript - review and critique: M. Sawada, T. Kawakami, M. Morita, Y. Aoki. Gene analysis (RASopathy): Y. Aoki.

\section{References}

1 Allanson JE, Roberts AE. Noonan Syndrome. In: Adam MP, Ardinger HH, Pagon RA, Wallace SE, Bean LJH, Stephens K, et al., editors. GeneReviews ${ }^{\circledR}$. Seattle, WA: University of Washington, Seattle; 1993.

2 Roberts AE, Allanson JE, Tartaglia M, Gelb BD. Noonan syndrome. Lancet. 2013 Jan;381(9863):333-42.

3 Aoki Y, Niihori T, Narumi Y, Kure S, Matsubara Y. The RAS/MAPK syndromes: novel roles of the RAS pathway in human genetic disorders. Hum Mutat. 2008 Aug;29(8):992-1006. 


\section{Case Reports in Neurology}

\begin{tabular}{l|l}
\hline Case Rep Neurol 2021;13:108-118 \\
\hline DOI: 10.1159/000512265 & $\begin{array}{l}\text { (C) 2021 The Author(s). Published by S. Karger AG, Basel } \\
\text { www.karger.com/crn }\end{array}$ \\
\hline
\end{tabular}

Ando et al.: Noonan Syndrome with KRAS Mutation and Nerve Root Hypertrophy

4 Burkitt Wright EM, Sach E, Sharif S, Quarrell O, Carroll T, Whitehouse RW, et al. Can the diagnosis of NF1 be excluded clinically? A lack of pigmentary findings in families with spinal neurofibromatosis demonstrates a limitation of clinical diagnosis. J Med Genet. 2013 Sep;50(9):606-13.

5 Silburn PA, Nicholson GA, Teh BT, Blair IP, Pollard JD, Nolan PJ, et al. Charcot-Marie-Tooth disease and Noonan syndrome with giant proximal nerve hypertrophy. Neurology. 1998 Apr;50(4):1067-73.

6 Manci EA, Martinez JE, Horenstein MG, Gardner TM, Ahmed A, Mancao MC, et al. Cardiofaciocutaneous syndrome (CFC) with congenital peripheral neuropathy and nonorganic malnutrition: an autopsy study. Am J Med Genet A. 2005 Aug;137(1):1-8.

7 DeRoos ST, Ryan MM, Ouvrier RA. Peripheral neuropathy in cardiofaciocutaneous syndrome. Pediatr Neurol. 2007 Apr;36(4):250-2.

8 Stark Z, Gillessen-Kaesbach G, Ryan MM, Cirstea IC, Gremer L, Ahmadian MR, et al. Two novel germline KRAS mutations: expanding the molecular and clinical phenotype. Clin Genet. 2012 Jun;81(6):590-4.

9 Spatola M, Wider C, Kuntzer T, Croquelois A. PTPN11 mutation manifesting as LEOPARD syndrome associated with hypertrophic plexi and neuropathic pain. BMC Neurol. 2015 Apr;15(1):55.

10 Maridet C, Sole G, Morice-Picard F, Taieb A. Hypertrophic neuropathy in Noonan syndrome with multiple lentigines. Am J Med Genet A. 2016 Jun;170(6):1570-2.

11 Conboy E, Dhamija R, Wang M, Xie J, Dyck PJ, Bridges AG, et al. Paraspinal neurofibromas and hypertrophic neuropathy in Noonan syndrome with multiple lentigines. J Med Genet. 2016 Feb;53(2):123-6.

12 Bertola DR, Pereira AC, Brasil AC, Suzuki L, Leite C, Falzoni R, et al. Multiple, diffuse schwannomas in a RASopathy phenotype patient with germline KRAS mutation: a causal relationship? Clin Genet. 2012 Jun; 81(6):595-7.

13 Santoro C, Giugliano T, Melone MA, Cirillo M, Schettino C, Bernardo P, et al. Multiple spinal nerve enlargement and SOS1 mutation: further evidence of overlap between neurofibromatosis type 1 and Noonan phenotype. Clin Genet. 2018 Jan;93(1):138-43.

14 Vizcaino MA, Belzberg A, Ahlawat S, Belakhoua S, Chen L, Staedtke V, et al. Localized Hypertrophic Neuropathy as a Neoplastic Manifestation of KRAS-Mediated RASopathy. J Neuropathol Exp Neurol. 2020 Jun;79(6):647-51.

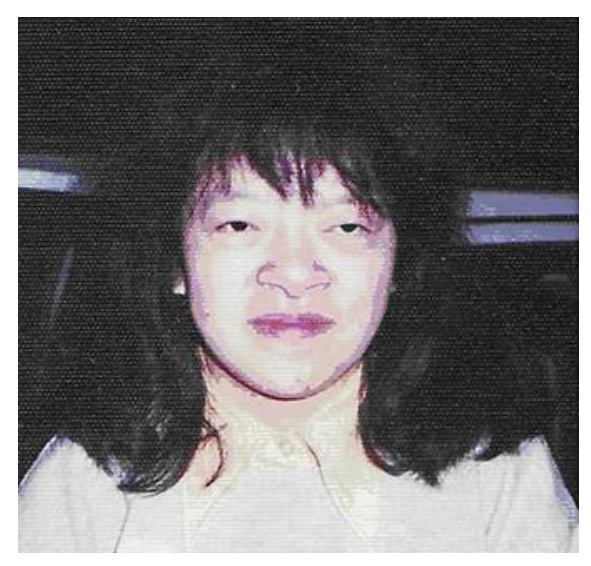

Fig. 1. Characteristic facial appearance. The patient showed a low-set hairline, hypertelorism, exophthalmos, flat root of the nose, wide wings of the nose, and thick lower lips. 


\section{Case Reports in Neurology}

\begin{tabular}{l|l}
\hline Case Rep Neurol 2021;13:108-118 \\
\hline DOI: 10.1159/000512265 & $\begin{array}{l}\text { @ 2021 The Author(s). Published by S. Karger AG, Basel } \\
\text { www.karger.com/crn }\end{array}$ \\
\hline
\end{tabular}

Ando et al.: Noonan Syndrome with KRAS Mutation and Nerve Root Hypertrophy
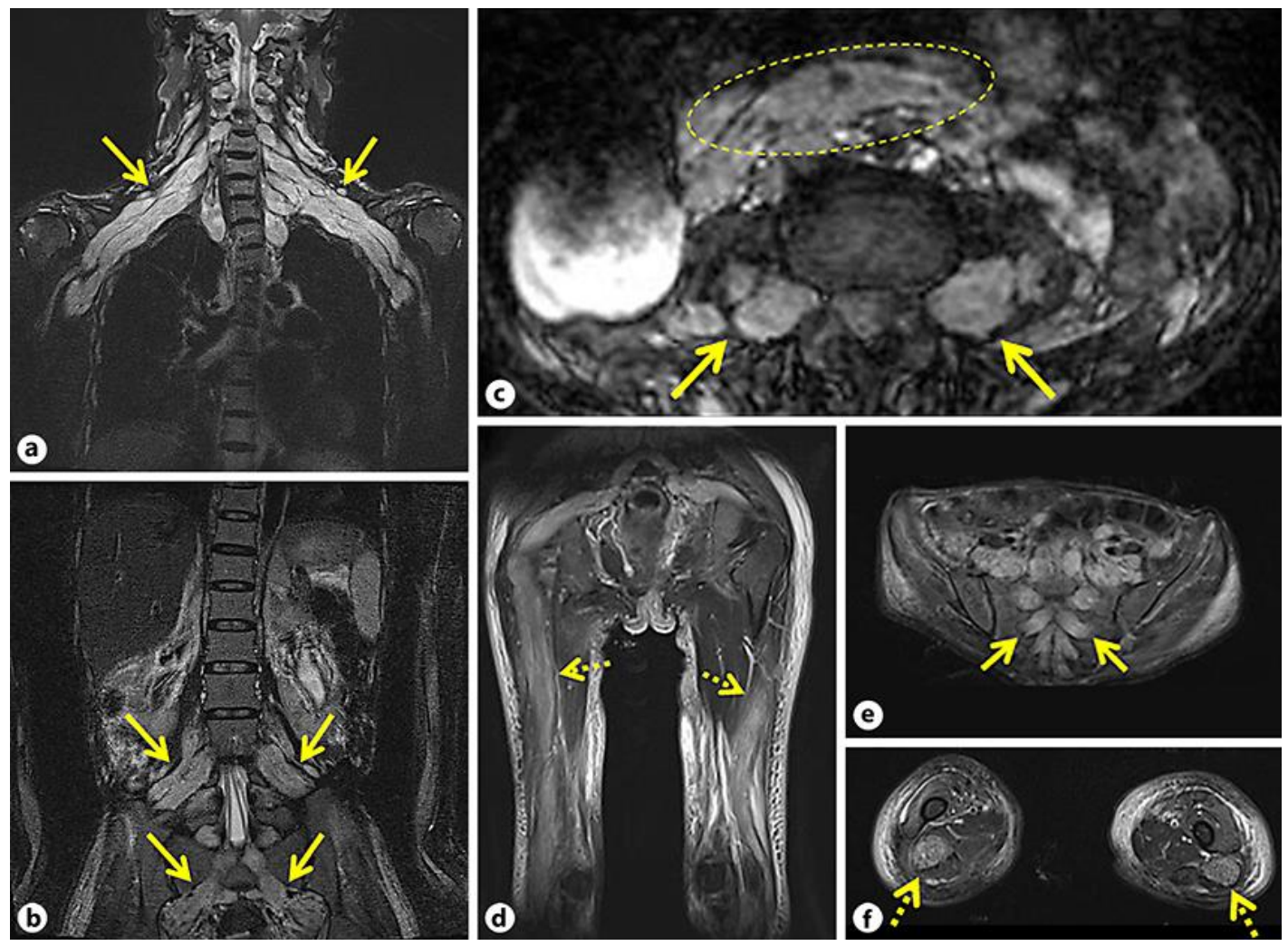

Fig. 2. Magnetic resonance images. Cervical plexus (a), lumbar plexus (STIR TR 2850 TE 89) (b), abdomen (Tfisp MPR TR 272.89 TE 2.15) (c), lower limbs (d), pelvis (e), and thighs (STIR TR 4200 TE 68) (f). These images show hypertrophy of the cervical, lumbar, and sacral plexus (solid arrows), a retroperitoneal tumor around the abdominal aorta and celiac artery (dashed circle), and hypertrophy of the sciatic nerve (dashed arrows). 
Case Reports in Neurology
Case Rep Neurol 2021;13:108-118

DOI: $10.1159 / 000512265$

(C) 2021 The Author(s). Published by S. Karger AG, Basel www.karger.com/crn

Ando et al.: Noonan Syndrome with KRAS Mutation and Nerve Root Hypertrophy
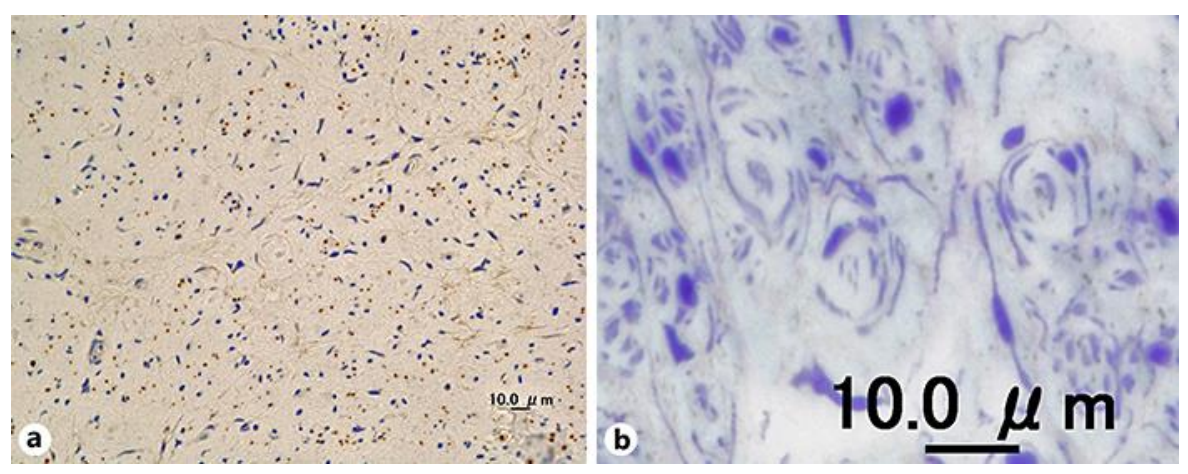

Fig. 3. Pathological findings of a sural nerve biopsy. Neurofilament antibody staining (a) and toluidine blue staining (b). We observed very few large, myelinated fibers, some onion bulb lesions, and no inflammatory cells. 


\section{Case Reports in Neurology}

Case Rep Neurol 2021;13:108-118

\begin{tabular}{l|l}
\hline DOI: $10.1159 / 000512265$ & $\begin{array}{l}\text { (c) } 2021 \text { The Author(s). Published by S. Karger AG, Basel } \\
\text { www.karger.com/crn }\end{array}$ \\
\hline
\end{tabular}

Ando et al.: Noonan Syndrome with KRAS Mutation and Nerve Root Hypertrophy

Table 1. Reported RASopathies with nerve root hypertrophy

\begin{tabular}{|c|c|c|c|c|c|c|c|c|}
\hline $\begin{array}{l}\text { Reference } \\
\text { (first } \\
\text { author) }\end{array}$ & $\begin{array}{l}\text { Relationship } \\
\text { of cases }\end{array}$ & $\begin{array}{l}\text { Patient } \\
\text { age/sex }\end{array}$ & $\begin{array}{l}\text { Clinical } \\
\text { diagnosis }\end{array}$ & Gene & Mutation & $\begin{array}{l}\text { Psychological/neurological } \\
\text { features }\end{array}$ & Imaging findings & Pathology \\
\hline Silburn [5] & $\begin{array}{l}\text { daughter } \\
\text { of case } 1\end{array}$ & $16 / \mathrm{F}$ & NS & $\begin{array}{l}\text { PMP22 } \\
\text { duplication - }\end{array}$ & & NCV normal & SR hypertrophy & NA \\
\hline Manci [6] & & $7 / \mathrm{M}$ & $\begin{array}{l}\text { CFC } \\
\text { syndrome }\end{array}$ & NA & & intellectual disability & skin PN hypertrophy & $\begin{array}{l}\text { skin biopsy: onion bulb } \\
\text { formation, axonal atrophy }\end{array}$ \\
\hline DeRoos [7] & & $27 / M$ & $\begin{array}{l}\mathrm{CFC} \\
\text { syndrome }\end{array}$ & NA & & $\begin{array}{l}\text { progressive gait disturbance, } \\
\text { NCV reduction }\end{array}$ & chronic hydrocephalus & NA \\
\hline Bertola [12] & & $23 / F$ & $\begin{array}{l}\text { Costello } \\
\text { syndrome }\end{array}$ & KRAS & p.Lys5Glu & $\begin{array}{l}\text { difficulty in relaxation of } \\
\text { hand muscle, abdominal pain, } \\
\text { nausea }\end{array}$ & SR hypertrophy & PN biopsy: schwannoma \\
\hline Stark [8] & case 2 & $3 / \mathrm{F}$ & $\begin{array}{l}\mathrm{CFC} \\
\text { syndrome }\end{array}$ & $K R A S$ & p.Lys147Glu & $\begin{array}{l}\text { sensorimotor disorder of } \\
\text { extremities }\end{array}$ & SR hypertrophy & NA \\
\hline Spatola [9] & & $41 / \mathrm{F}$ & NSML & PTPN11 & p.Thr468Met & $\begin{array}{l}\text { patchy sensorimotor disorder } \\
\text { of extremities }\end{array}$ & SR hypertrophy & NA \\
\hline Maridet [10] & & $43 / F$ & NSML & PTPN11 & p.Thr468Met & skin tumor & SR hypertrophy & NA \\
\hline \multirow[t]{3}{*}{ Conboy [11] } & case 1 & $28 / \mathrm{M}$ & NSML & PTPN11 & p.Thr468Met & skin tumor, NCV reduction & SR hypertrophy & NA \\
\hline & case 2 & $50 / M$ & NSML & PTPN11 & p.Thr468Met & $\begin{array}{l}\text { autism spectrum disorder, } \\
\text { back pain, skin tumor, NCV } \\
\text { reduction }\end{array}$ & SR hypertrophy & $\begin{array}{l}\text { PN and intrapelvic } \\
\text { nerve biopsy: onion bulb } \\
\text { formation }\end{array}$ \\
\hline & case 3 & $16 / F$ & NSML & PTPN11 & p.Thr279Cys & $\begin{array}{l}\text { chest pain, hearing loss, pain } \\
\text { and weakness of lower limb } \\
\text { (operation) }\end{array}$ & $\begin{array}{l}\text { paraspinal tumor, } \\
\text { lumbar root hypertrophy }\end{array}$ & $\begin{array}{l}\text { radial nerve operation } \\
\text { (past history): } \\
\text { schwannoma }\end{array}$ \\
\hline \multirow[t]{2}{*}{ Santoro [13] } & case 1 & $15 / \mathrm{M}$ & NSML & SOS1 & p.Ser548Arg & intellectual disability & no SR hypertrophy & NA \\
\hline & $\begin{array}{l}\text { mother of } \\
\text { case } 1\end{array}$ & $40 / \mathrm{F}$ & NSML & $\operatorname{sos} 1$ & p.Ser548Arg & $\begin{array}{l}\text { epilepsy, depression, } \\
\text { insomnia, behavior and } \\
\text { attention disorder, } \\
\text { sensorimotor disorder of } \\
\text { extremities }\end{array}$ & SR hypertrophy & NA \\
\hline Vizcaino [14] & & $11 / \mathrm{M}$ & $\begin{array}{l}\text { KRAS- } \\
\text { mediated } \\
\text { RASopathy }\end{array}$ & KRAS & C38_40dupGCG & no detailed mention & $\begin{array}{l}\text { SR hypertrophy, PN } \\
\text { hypertrophy }\end{array}$ & $\begin{array}{l}\text { PN biopsy: onion bulb } \\
\text { formation, Schwann cell } \\
\text { processes, axonal loss }\end{array}$ \\
\hline Our report & & $45 / \mathrm{F}$ & NS & KRAS & p.Tyr71Asp & $\begin{array}{l}\text { intellectual disability, } \\
\text { progressive gait disturbance, } \\
\text { NCV reduction }\end{array}$ & $\begin{array}{l}\text { SR hypertrophy, } \\
\text { retroperitoneal tumor, } \\
\text { PN hypertrophy }\end{array}$ & $\begin{array}{l}\text { PN biopsy: onion bulb } \\
\text { formation }\end{array}$ \\
\hline
\end{tabular}

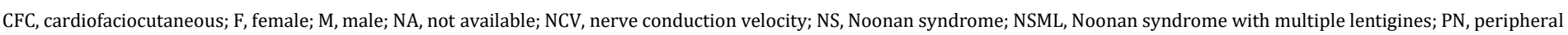
nerve; SR, spinal root. 